\title{
3000 FEET OF QUATERNARY AND ? TERTIARY DEPOSITS IN
} TEXAS, U.S.A.

Srr,-At Galveston, Texas, a well has recently been bored (in search of water for a city supply) in which the following formations are reported (in the New York "Engineering and Mining Journal") to occur. This well is said to be the deepest on the sea-coast of the United States.

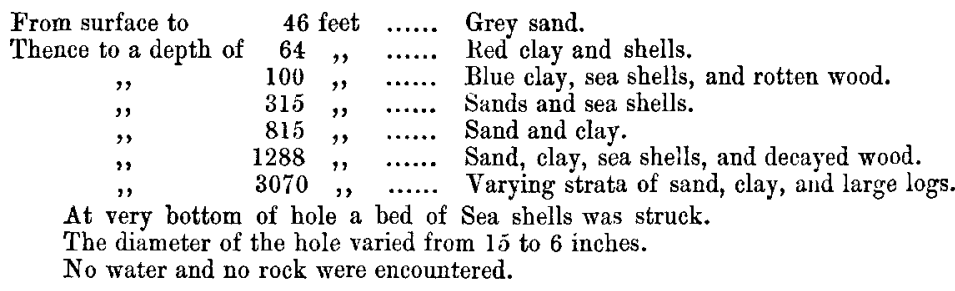

Perhaps this may meet the eye of someone who ean supply more detailed information in regard to this interesting section, and say something as to the nature of the sea shells, fossil wood, etc., brought up.

ErIE, PA., U.S.A., 6th December, 1892.

\section{W. S. Gresley.}

\section{“THE MALVERN CRYSTALLINES."}

SrR,-May I be allowed to make one or two brief remarks on the criticism of my friend, Dr. Calloway, in this month's number of the Geor. Mag.

While attaching a very high value to his work, I still fancy I have broken new ground to some extent by presenting the case of the Malvern Crystallines as a physical problem to be attacked, first of all in the light of the field-evidence, for observing and collecting which I had exceptional opportunities in the early part of the year. I may say that his general omission from consideration of the chemical and physical factors of such a problem takes the sting out of many of Dr. Calloway's criticisms. I cannot regard it as a valid criticism to quote from what is little more than a note in Prof. Phillips' later work, as if it neutralized the value of the speculations of his earlier work, to which I referred. It does not alter my estimate of the value of his earlier views, which went so far in anticipation of some recent advances in petrological science. Does Dr. Calloway think he is appealing from Phillips' drunk to Phillips' sober? Nor does a negative deduction from Dr. Callaway's general experience of the Malverns do much to damage a case specifically cited by me in the quarry above West Malvern Churck. Creditably again is so variable a factor with different minds, that such a retreat from the objective to the subjective does not appear to me to be of a very high order of scientific reasoning. The puzzling case of the hornblende and the two felspars mentioned on p. 546 seems to me (so far as I can follow the description) to admit of an easy explanation as a case of pure and simple segregation as crystallization progressed in the mass, if the variable fluxing-action 
of the different bases is fully considered, and to which I have drawn attention in my paper.

I do not for a moment pretend to have reached the end of my studies of this interesting complex of rocks, and shall await with much interest the appearance of the promised paper. As to my 'shear-planes' (not 'shear-zones'), it is just because they have nothing to do with the 'schist-making' processes, that they afford such strong negative evidence (while they record the action of dynamic forces on a grand scale) against the notion of the schistmanufacture having been wrought generally in solid crystalline masses. The general principles of my work are sufficiently before the world for those who care to know them to do so.

Wallington College, Berks, $16 t h$ Dec., 1892.

A. Inving.

\section{GLACIAL GEOLOGY.}

SrR,-I quite agree with Mr. R. M. Deeley in your last number, when he writes that he has "read with much interest the papers by Mr. Mellard Reade and Mr. Percy Kendall in your July and November issues. On the one hand we have the submergence theory proved up to the hilt, and on the other, the glacier theory sustained with equal show of reason. Does it strike the combatants that they may both be right and both be wrong?"

It is difficult to conceive a Glacial Period without the usual phenomena appertaining to both land and coast ice. Why should we, therefore, restrict ourselves to either the one agency or the other, when there must have been marine and land moraine drifts contemporaneously forming. The Gloppa deposit at Oswestry described by Mr. Nicholson in the Q.J.G.S. Vol. xlviii. p. 86 may be taken as a typical marine drift with its glaciated lake district erratics and Boreal Fauna of recent shells, occurring from 1070 to 1120 feet above O. D., yet twelve miles to the north-west of the Gloppa in the upper valley of the Dee from the neighbourhood of Corwen to Bala Lake, which is only 540 feet above O. D.- the drift is entirely local and does not contain any fragments of recent marine shells, though 500 feet below the Gloppa deposit.

The plain interpretation of this-to my mind-is that ice filled the upper valley of the Dee and the surrounding country to a higher level than that to which the marine drift of the Gloppa obtained. The Gloppa deposit like the other deposits of high level marine drift as Moeh Tryfean, Macclesfield, and Halkyw (Flintshire), are situated upon the outskirts of the mountainous areas to which they belong. This, I think, would suggest that such mountainous areas were covered with a thickness of ice in their central portions, which excluded the high level marine drift from the interior mountains and valleys.

William Shoner.

Upton Park, Chester, Dec. 16th, 1892. 